\title{
PRAKTIK RENTENIRISASI PERSPEKTF EKONOMI SYARIAH DAN SOSIOLOGI (STUDI DI KECAMATAN PUNGGUR LAMPUNG TENGAH)
}

\author{
Ika Trisnawati Alawiyah \\ Institut Agama Islam Ma'arif NU (IAIMNU) Metro Lampung \\ Email; ikaalawiyah86@gmail.com
}

\begin{abstract}
This research was conducted to answer the question of how to practice sharia investment sharia perspective and sociology in Punggur, Central Lampung District. This study aims to determine the practice of a loan shark sharia economic perspective and sociology in Punggur, Central Lampung District. This type of research is field research conducted in Punggur District, Central Lampung Regency. This study uses a descriptive qualitative approach that is a way to expose accurate information obtained from the community in the District of Punggur, Central Lampung relating to the practice of a loan shark. Data sources used are primary and secondary data sources. The data collection method uses the method of observation, interviews and documentation with technical analysis of deductive thinking. The results of research on a loan shark practices in the community of Punggur Subdistrict, the perspective of Islamic economics is very contrary to regulation in Islamic law, because those who practice muamalah are ribawi. While, according to the sociological perspective of the loan sharks, this is a solution for some people to meet their daily needs. The facilities provided such as loan amount, faster and more efficient time, how to pay, without collateral, and other agreements are considered by the community when making loans.
\end{abstract}

Keywords: Loan Sharks, Islamic Economics, Sociology

\begin{abstract}
Abstrak
Penelitian ini dilakukan untuk menjawab pertanyaan bagaimana praktik rentenirisasi perspektif ekonomi syariah dan sosiologi di Kecamatan Punggur Lampung Tengah. Penelitian ini bertujuan untuk mengetahui praktik rentenirisasi perspektif ekonomi syariah dan sosiologi di Kecamatan Punggur Lampung Tengah. Jenis penelitian ini adalah penelitian lapangan (field research) yang dilakukan di Kecamatan Punggur Kabupaten Lampung Tengah. Penelitian ini menggunkan pendekatan kualitatif yang bersifat deskriptif yaitu cara memaparkan informasi-informasi yang akurat yang diperoleh dari masyarakat di Kecamatan Punggur Lampung Tengah yang berkaitan dengan praktik rentenirisasi. Sumber datayang digunakan adalah sumber data primer dan sekunder. Metode pengumpulan data menggunakan metode observasi, wawancara dan dokumentasi dengan teknis analisa berpikir deduktif. Hasil penelitian terhadap praktek rentenir di masyarakat Kecamatan Punggur perspektif ekonomi islam yaitu sangat bertentangan dengan hukum
\end{abstract}

Website: http://jurnal.radenfatah..ac.id/index.php/ieconomics 
dan syariat islam karena mereka yang melakukan praktek muamalah secara ribawi. Sedangkan menurut perspektif sosiologi para rentenir ini menjadi solusi bagi para sebagian masyarakat untuk memenuhi kebutuhan hidupnya. Kemudahan-kemudahan yang diberikan seperti besar pinjaman, waktu yang lebih cepat dan efisien, cara membayar, tanpa jaminan, dan kesepakatan-kesepakatan lain menjadi pertimbangan masyarakat ketika melakukan pinjaman.

\section{Kata Kunci: Rentenir, Ekonomi Syariah, dan Sosiologi}

\section{Pendahuluan}

Permasalahan ekonomi yang terjadi dalam kehidupan masyarakat memang tidak ada habisnya. Hal ini dikarenakan terjadinya krisis ekonomi yang tentunya sangat meresahkan masyarakat. Dalam kehidupan dimasyarakat selalu berusaha mengerjakan pekerjaan yang dapat mencukupi kebutuhan mereka.1

Dari kebutuhan masyarakat yang terus meningkat dan pendapatan yang rendah menyebabkan masyarakat memilih untuk memenuhi kebutuhannya dengan cara berutang. Keinginan untuk berutang timbul karena adanya kebutuhan tertentu untuk menuntut adanya persediaan uang yang melebihi pendapatan. Kebutuhan tersebut dapat berupa kebutuhan yang sudah direncanakan atau kebutuhan yang mendesak secara tiba-tiba.2 Mengenai utang masyarakat banyak melakukan pinjaman ke rentenir karena akses berutang kepada rentenir sangatlah mudah meskipun harus menanggung bunga yang tinggi dan bahkan lebih besar dari utang pokoknya hal ini dikarenakan kebutuhan hidup dan kebutuhan yang medesak.

Rentenir merupakan seseorang yang melakukan sebuah kegiatan peminjaman uang atau modal. Kegiatan rente pada dasarnya suatu aktifitas dimana seseorang meminjamkan uang dengan bunga yang berlipat-lipat yang memungkinkan bunga tersebut melebihi utang pokoknya jika cicilannya terlambat.3 Dalam transaksi utang piutang adalah menghindari unsur riba. Riba merupakan suatu tujuan sentral dari semua ajaran moral yang ada pada semua masyarakat.4 Pada sistem ekonomi syariah juga telah melarang riba.5 Menganai riba telah jelaskan dalam Al-Qur'an surat Ali Imran ayat 130.

1 Cica, "Dampak Praktik Rentenir Terhadap Kesejahteraan Ekonomi Masyarakat Di Kelurahan Pattinggalloang Baru Kecamatan Ujung Tengah Makassar” (Skripsi, Universitas Alauddin Makassar, 2018), hlm. 1 .

2 Chici Amedea dan Mira Hasti Hasmira, "Pemanfaatan Utang Oleh Ibu-ibu Rumah Tangga Pada Rentenir di Jorong Kuranji Kecamatan Guguak VIII Koto Kabupaten Lima Puluh Kota,” Jurnal Perspektif: Jurnal Kajian Sosiologi dan Pendidikan Vol. 3, no. 1 (2020): hlm. 153.

3 Ilas Korwadi Siboro, "Rentenir (Analisis Terhadap Fungsi Pinjaman Berbunga Dalam Masyarakat Rokan Hilir Kecamatan Bagan Sinembah Desa Bagan Batu),” Jurnal Jom Fisip Vol. 2, no. 2 (2015): hlm. 1.

4 Institut Bankir Indonesia, Bank Syariah: Konsep, Produk dan Implementasi Operasional (Jakarta: Djambatan, 2001), hlm. 45.

5 Fazlur Rahman, Doktirn Ekonomi Islam (Yogyakarta: PT. Dana Bhakti Wakaf, 1995), hlm. 7.

Website: http://jurnal.radenfatah..ac.id/index.php/ieconomics 


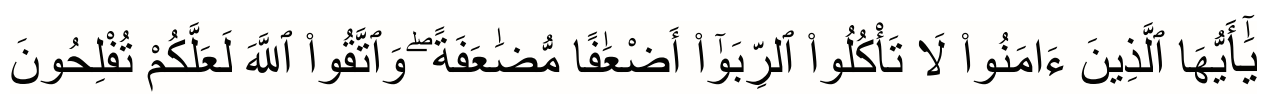

Artinya: Hai orang-orang yang beriman, janganlah kamu memakan Riba dengan berlipat ganda dan bertakwalah kaтu kepada Allah supaya kamu mendapat keberuntungan.

Adanya rentenir meskipun bersifat eksploitatif, tetapi justru terlibat seolah-olah mambantu ekonomi masyarakat. Kehadiran rentenir dimata masyarakat khusunya golongan strata menengah kebawah ternyata dianggap sangat membantu untuk mendapatkan uang dan dalam waktu cepat, pola hubungan masyarakat dengan rentenir yang telah memberinya pinjaman, walaupun rentenir bersikap loyal, tetapi sesungguhnya rentenir telah menciptakan ketergantungan ekonomi bagi masyarakat.6

Terkait dengan keberadaan rentenir yang pada saat ini masih banyak dikalangan masyarakat, terutama di Kecamatan Punggur. Praktik rentenir di Kecamatan Punggur yang dalam hal ini masyarakat melakukan pinjaman untuk memenuhi kebutuhan yang biasanya tidak ada pilihan lain karena meminjam di bank atau lembaga keuangan lain persyaratannya rumit, sehingga rentenir sebagai solusi dalam memecahkan permasalahan perekonomian pada masyarakat. Dalam hal ini dengan meminjam uang di rentenir justru menyengsarakanakan dan juga bisa berdampak sistemik mematikan niklim usaha di kalangan masyarakat bawah.

Mengenai permasalah tersebut penulis merasa tertarik untuk melakukan penelitian yang mana praktik rentenir masih banyak dilakukan di kalangan masyarakat dengan bunga yang tinggi, tetapi masih terdapat masyarakat yang meminjam uang di rentenir dengan alasan meminjam di bank atau lembaga keuangan lain persyaratannya rumit dan tidak ada pilihan lain. dengan demikian penulis merasa penting untuk melakukan penelitian ini dengan dilihat dari sisi ekonomi syariah dan sosiologi.

Dari pemaparan diatas, maka penulis mengangkat judul mengenai Praktik Rentenirisasi Perspektf Ekonomi Syariah dan Sosiologi (Studi di Kecamatan Punggur Lampung Tengah).

\section{Rentenir}

Secara harfiah rentenir berasal dari kata Rente yang artinya renten, bunga uang. Kata ini tidak jauh berbeda dengan makna riba yang secara bahasa berarti Ziyadah (tambahan) baik dalam transaksi jual beli maupun pinjam meminjam. Institusi yang memperoleh profit melalui penarikan bunga disebut dengan rente yaitu seperti Bank, Koperasi dan lembaga

6 Muhammad Luthfi, "Praktik Rentenir Dalam Perspektif Hukum Ekonomi Syariah”, hlm. 5.

Website: http://jurnal.radenfatah..ac.id/index.php/ieconomics 
pengkreditan lainnya. sedangkan individu yang memperoleh keuntungan melalui penarikan bunga disebut dengan rentenir.7

Secara umum rentenir adalah bentuk usaha perorangan yang memberi kredit berupa uang tunai, sumber dana berasal dari modal sendiri, disamping itu juga pinjaman orang lain di Kota dengan tingkat suku bunga sebesar antara 5 sampai dengan 10 persen dan sering kali dari non pribumi. 8 Karena pada dasarnya memang rentenir meminjamkan uang kepada seseorang dengan mengambil keuntungan yang tinggi yaitu dengan bunga.

Sedangkan secara praktis rentenir merupakan bank yang melakukan penghimpunan dana dan penyaluran pinjaman secara aktif dengan lansung mendatangi nasabah dan kebanyakan dilakuakn oleh perorangan atau individu yang memiliki finansial cukup kuat di suatu kehidupan masyarakat. Tetapi dalam upaya bantuan pinjaman oleh rentenir pada praktiknya kerap kali memberikan pinjaman dengan adanya penambahan pengembalian terhadap nilai yang dipinjam oleh masyarakat.9 Dengan adanya rentenir kebutuhan rumah tangga atau untuk modal usaha dapat terpenuhi.

Berdasarkan pengertian diatas penulis dapat menyimpulkan bahwa rentenir adalah seseorang yang memberi pinjaman berupa uang dengan sistem bunga yang tinggi, pinjaman tersebut biasanya tidak diberikan melalui lembaga seperti bank atau lembaga keuangan lainnya.

\section{Ekonomi Syariah}

\section{Pengertian Ekonomi Syariah}

Secara etimologi ekonomi berasal dari bahasa Oikononemia (Yunani) yang terdiri dari dua kata yaitu oicos yang artinya rumah dan nomos yang artinya aturan. Dengan demikian kata ekonomi berarti subuah aturan untuk menyelenggarakan kebutuhan hidup manusia dalam rumah tangga baik rumah tangga masyarakat maupun rumah tangga negara.10

Sedangkan kata syariah berasal dari kata syara'a yang berarti menempuh, menjelaskan dan menunjukkan jalan.11 Secara bahasa yaitu jalan untuk menuju sumber air yang dapat diartikan sebagai jalan untuk menuju sumber pokok kehidupan.12

7 Fuad Mohd Fachruddin, Riba dalam Bank, Koperasi, Perseroan dan Assuransi (Bandung: PT AlMa'arif, 1993), hlm. 37.

8 Frans E. Panjaitan dan Nofrion Ratna Wilis, "Praktik Pelepasan Uang/Rentenir di Nagari Lubuk Basung Kabupaten Agam Sumatera Barat,” Jurnal Buana Vol. 2, no. 1 (2018): hlm. 399.

9 Yeyen Parlina, "Praktik Pinjaman Renternir dan Perkembangan Usaha Pedagang di Pasar Prapatan Penjalin Majalengka," hlm. 135.

10 Abdullah Zaky Al-Kaaf, Ekonomi dalam Perspektif Islam (Bandung: PT. Pustaka Setia, 2002), hlm. 18.

11 Nurhayati, "Memahami Konsep Syariah, Fikih, Hukum, dan Ushul Fikih," Jurnal Hukum Ekonomi Syariah Vol. 2, no. 2 (2018): hlm. 127.

12 H. Abdul Manan, Pembahatuan Hukum Islam di Indonesia (Depok: Kencana, 2017), hlm. 70.

Website: http://jurnal.radenfatah..ac.id/index.php/ieconomics 
Dengan demikian syariah sebagai pedoman dalam hubungan dengan Allah SWT, sesama, dan lingkungan hidupnya.

Jika kata "ekonomi" dan "syariah" disatukan maka menjadi pengertian sebuah konsep ekonomi yang dijalankan berdasarkan nilai-nilai dan prinsip ajaran Islam yang bersumber pada Al-Qur'an dan Hadits, yang berorientasi pada Allah. Al-Qur'an dan Hadits adalah sebuah pengikat tata aturan dalam menjalankan seluruh aktifitas ekonomi. Mengenai hal ini pencapaian ridha Allah adalah sebagai titik tolak dan lahirnya ekonomi syariah. 13

Jadi pemaparan di atas ekonomi syariah adalah suatu aturan yang bersumber dari Al-Qur'an dan Hadits yang dijadikan sebuah pedoman dalam memenuhi kebutuhan hidup setiap manusia demi menjaga kelangsungan hidupnya supaya tidak bertentangan dengan ajaran Islam.

\section{Praktik Rentenir Persektif Hukum Perbankan}

Pada hukum positif Indonesia tidak melarang adanya bunga dalam setiap tindakan pinjam meminjam. Ini sesuai dengan pasal $1754 \mathrm{BW}$ dan pasal $1765 \mathrm{BW}$ "bahwa adalah diperbolehkan memperjanjikan bunga atas pinjaman uang atau barang lain yang habis karena pemakaian".. Adanya perjanjian seperti ini baik antara orang perorang atau badan hukum menurut hukum perdata, hukum pidana, maupun hukum adat tidak dilarang. Namun, jika dilihat dari hukum islam, transaksi pinjam meminjam dengan bunga merupakan tindakan yang dilarang dan diharamkan. 14

Dari penjelasan diatas dalam pasal 46 ayat (1) Undang-undang No. 10/1998 yang merumuskan "barang siapa yang menghimpun dana dari masyarakat dalam bentuk simpanan tanpa izin dari pimpinan Bank Indonesia sebagaimana yang dimaksud dalam pasal 16, diancam dengan pidana penjara sekurang-kurangnya lima tahun dan paing lama 15 tahun serta denda sekurang-kurangnya Rp. 10 miliar dan paling banyak Rp 200 miliar". 15

Berdasarkan rumusan tersebut yang dilarang adalah perbuatan menghimpun dana dari masyarakat, tetapi perbuatan yang dilakukan oleh pihak yang menyalurkan dana dengan bunga (rentenir) tidak dilarang dalam Undang-undang Perbankan, sehingga praktik rentenir tidak dikualifisir sebagai suatu tindak pidana perbankan. 16

13 Yuliyani, "Konsep dan Peran Strategi Ekonomi Syariah Terhadap Isu Kemiskinan," Jurnal Iqtishadia Vol. 8, no. 1 (2015): hlm. 138.

14 Moh. Zainol Arief dan Sutrisni, "Praktik Rentenir Penghambat Terwujudnya Sistem Hukum

Perbankan Syariah di Kabupaten Sumenep." hlm. 68.

15 Flora Dianti, "Hukum Online.Com,",

https://m.hukumonline.com/klinik/detail/ulasan/it4e91424b20cbe/dapatkah-rentenir-dipidana-/. diakses 23 Februari 2020

16 Flora Dianti, "Hukum Online.Com,",

https://m.hukumonline.com/klinik/detail/ulasan/it4e91424b20cbe/dapatkah-rentenir-dipidana-/. diakses 23 Februari 2020.

Website: http://jurnal.radenfatah..ac.id/index.php/ieconomics 
Besar bunga yang diperjanjikan tidak disebutkan secara jelas. Melainkan hanya dikatakan "asal tidak dilarang oleh undang-undang". Dalam hal ini pembatasan bunga yang tinggi hanya dikenal dengan "Woeker-ordonantie" 1938, yang termuat dalam Staatblaad (Lembaran Negara) tahun 1938 No. 524 bahwa, antara kewajibankewajiban bertimbal balik dari kedua belah pihak yang semula terdapat ketidakseimbangan yang luar biasa, maka orang yang berhutang dapat meminta kepada hakim untuk menurunkan bunga yang telah diperjanjikan atau membatalkan perjanjiannya. 17

Berdasarkan penjelasan tersebut sudah jelas bahwa praktek pinjam-meminjam uang yang disertai dengan bunga adalah tindakan yang legal dan dibenarkan oleh hukum perbankan.

\section{Praktik Rentenir Prespektif Ekonomi Syariah}

Perkembangan praktik pinjam meminjam semakin banyak dilakukan oleh masyarakat seperti pinjam meminjam kepada rentenir. Menurut ekonomi islam bahwa melakukan kredit dengan instrument utamanya adalah bunga jelas di haramkan. Karena bunga memiliki pengertian yang sama dengan riba. Oleh sebab itu, praktek rentenirisasi dalam ekonomi islam bertentangan dengan nilai-nilai syara' sehingga harta yang dihasilkan baik sedikit atau banyak hukumnya jelas-jelas haram.18

Mengenai riba telah dijelaskan dalam Al-Qur'an yaitu pada surat Ar-Ruum ayat 39 yaitu

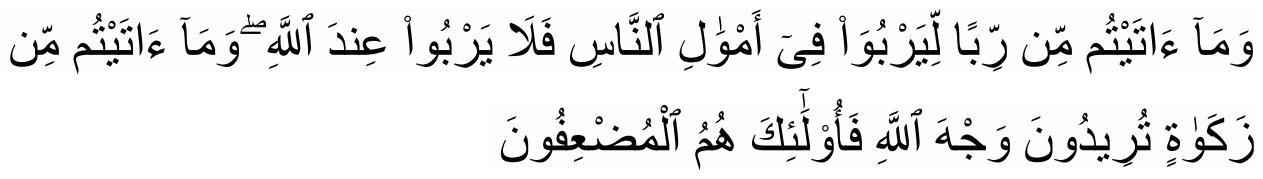

Artinya: Dan sesuatu riba (tambahan) yang kamu berikan supaya dia menambah pada harta manusia, maka riba itu tidak menambah pada sisi Allah. Dan apa yang kamu berikan berupa zakat yang kamu maksudkan untuk mencapai keridhoan Allah, maka (yang berbuat demikian) itulah orang-orang yang melipatgandakan pahalanya. 19

Pada ayat diatas dijelaskan bahwa harta yang diberikan sebagai hutang dan dengan tujuan mendapatkan riba dan mencari tambahan dari hutang tersebut, agar ia tumbuh dan menjadi banyak, sebenarnya disisi Allah tidak bertambah, karena Allah

17 R Subekti, Aneka Perjanjian, 1985, hlm. 130.

18 Jajang Urjaman, "Peranan Baitul Mall Wattamwil Dalam Mengatasi Dampak Negatif Praktek Rentenir" (Skripsi, Jakarta, UIN Syarif Hidayatullah, 2010), hlm. 18-22.

19 Al-Qur'an surat Ar-Ruum [30] : 39.

Website: http://jurnal.radenfatah..ac.id/index.php/ieconomics 
justru menghancurkannya dan membatalkannya. Sementara apa yang diberikan dalam bentuk zakat dan sedekah kepada orang-orang yang berhak mnerimanya demi mencari keridharaan Allah, maka inilah yang diterima oleh Allah.

Pendapat dari berbagai ahli tafsir (Jumhur al-mufassirin) tentang riba pada ayat tersebut adalah bentuk pemberian (al-'athiyyah) yang disampaikan oleh seseorang kepada orang lain bukan dengan maksud untuk mendapatkan ridha Allah Swt., tetapi hanya untuk memperoleh kenikmatan duniawi semata. Oleh sebab itu, pelaku riba tidak akan mendapatkan pahala dari Allah Swt. atas pemberiannya itu. Ini jelas berbeda dengan zakat, yang apabila menunaikannya, para pelakunya hanya ingin memperoleh ridha Allah Swt.20

Pada surat Al-Baqarah ayat 275 juga dijelaskan mengenai larangan riba.

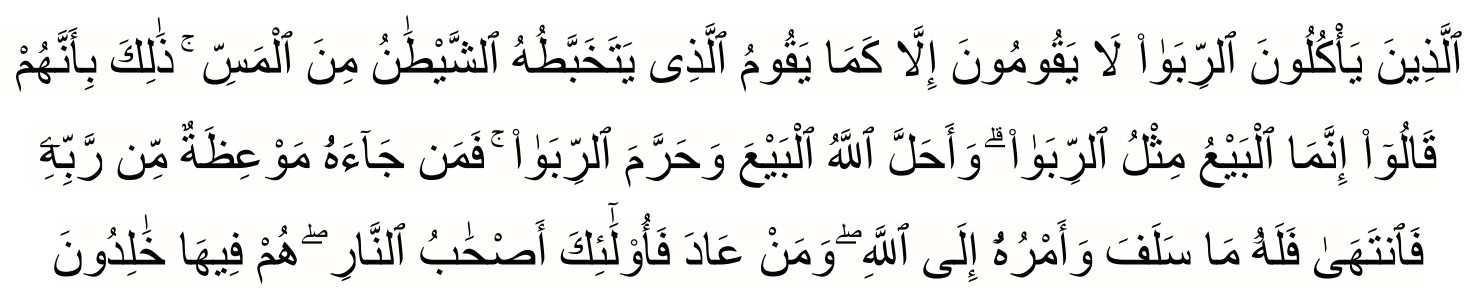

Artinya: Orang-orang yang Makan (mengambil) riba tidak dapat berdiri melainkan seperti berdirinya orang yang kemasukan syaitan lantaran (tekanan) penyakit gila. Keadaan mereka yang demikian itu, adalah disebabkan mereka berkata (berpendapat), Sesungguhnya jual beli itu sama dengan riba, Padahal Allah telah menghalalkan jual beli dan mengharamkan riba. orang-orang yang telah sampai kepadanya larangan dari Tuhannya, lalu terus berhenti (dari mengambil riba), Maka baginya apa yang telah diambilnya dahulu (sebelum datang larangan); dan urusannya (terserah) kepada Allah. orang yang kembali (mengambil riba), Maka orang itu adalah penghuni-penghuni neraka; mereka kekal di dalamnya. (Q.S Al-Baqarah : 275)21

Dari ayat diatas dijelaskan bahwa Allah telah menghalalkan jual beli dan mengharamkan riba. Siapa saja yang menghindari riba, maka keberuntungan baginya. Apabila melakukan praktik riba dan menjalankan sampai kepadanya larangan Allah, maka sesungguhnya dia pantas memperoleh siksaan. Orang yang mengambil riba tidak tenteram jiwanya seperti orang kemasukan syaitan.

20 Abd al-'azhim Jalal Abu Zayd, "Fiqh al-Riba Dirasah Muqaranah wa Syamilah li Tathbiqat alMu'ashirah" (Bayrut: Mu'assasah al-Risalah, 1425 H/2004M), hlm 70.

21 Al-Qur'an surat Al-Baqarah : 275.

Website: http://jurnal.radenfatah..ac.id/index.php/ieconomics 
Menurut M. Quraish Shihab bahwa dari segi bahasa riba berarti "kelebihan”. Jika hanya memaknai riba sebagai kelebihan, maka orang-orang yang melakukan praktik ini menganggap riba adalah suatu keuntungan meskipun dalam ayat al-Qur'an menyatakan "Tuhan menghalalkan jual beli dan mengharamkan riba". pada dasarnya hukum halal dan haram pada ayat tersebut, tidak akan ditentukan tanpa adanya "sesuatu" yang membedakannya, dan "sesuatu" itulah yang menyebabkan keharaman riba.22

Selain ayat diatas, larangan mengenai riba diperjelas pada surat Al-Imron ayat 130 yaitu

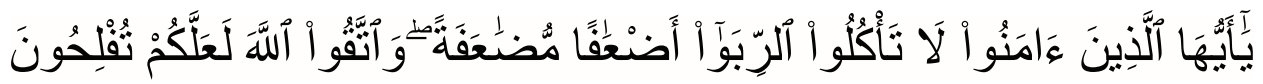

Artinya: Hai orang-orang yang beriman, janganlah kamu memakan Riba dengan berlipat ganda dan bertakwalah kamu kepada Allah supaya kamu mendapat keberuntungan.23

Ayat ini menerangkan bahwa bagi orang-orang yang beriman untuk menjauhi riba dengan segala jenisnya dan tidak boleh mengambil tambahan dalam pinjaman dengan melebihi jumlah modal, walaupun sedikit apalagi sampai berjumlah banyak serta menjadi berlipat ganda setiap kali jatuh tempo pembayaran utang.

Pendapat yang dikemukakan oleh Sayyid Quthub tentang adh'afan mudha'afah adalah sifat yang sangat melekat pada riba. Untuk itu, walaupun ditetapkan dalam jumlah yang sedikit saja, maka seiring berjalannya waktu, riba yang sedikit tersebut jumlahnya akan terus berlipat ganda.24 Jika pendapat Quthhb ini diterima, maka hukum riba tetaplah haram, baik dalam jumlah yang sedikit ataupun dalam jumlah yang berlipat ganda.

Selain dijelaskan dalam Al-Qur'an larangan riba juga diterangkan dalam hadits yaitu:

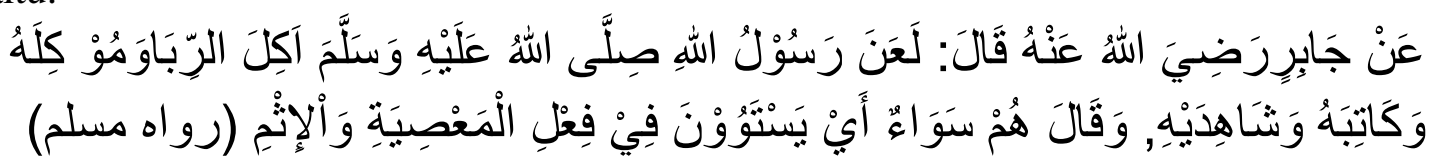

Artinya: Dari Jabir ra. Ia berkata: "Rasulullah Saw melaknat orang-orang yang makan riba, orang-orang yang memberi makan dengan uang riba, orangorang yang mencatat (juru tulis) dalam transaksi riba dan juga saksisaksinya." Beliau bersabda: "Mereka itu sama-sama berbuat maksiat dan dosa." (HR. Muslim).25

22 Harun, “Riba Menurut Pemikiran M. Quraish Shihab,” Suhuf 27, no. 1 (Mei 2015), hlm. 49.

23 Al-Qur'an Surat Al-Imron :130.

24 Sayyid Quthhb, Fi Zhilal al-Qur'an,(Dar al-Fikr),Jilid IV, hlm. 74.

25 Mustafa Daib Al-Bigha, Tadzhib: Kompilasi Hukum Islam Ala Madzhab Syafi'i (Surabaya: AlHidayah, 2008), hlm. 319.

Website: http://jurnal.radenfatah..ac.id/index.php/ieconomics 
Dari hadits diatas bawasannya sudah jelas, Rasulullah melaknat bagi orang melakukan segala jenis yang berbentuk riba seperti memakan, memberi maupun juru tulis.

Dengan demikian dilihat dari sisi ekonomi yang dimaksud dengan rente suatu faktor produksi tertentu adalah kelebihan pembayaran atau biaya minumum yang diperlukan untuk tetap mengonsumsi faktor produksi tersebut. Rentenir sebagai pihak yang memberikan dana dan membungakan dana tersebut atau biasa disebut dengan lintah darat.26

\section{Sosiologi Masyarakat Pada Praktik Rentenir}

\section{Rentenir Dalam Pandangan Sosiologi Masyarakat}

Kehidupan sehari-hari masyarakat selalu membutuhkan uang untuk memenuhi kebutuhan pokok. ${ }^{27}$ Faktanya pada saat ini, masyarakat yang memiliki pendapatan kecil sering dihadapkan pada keharusan untuk mengeluarkan jumlah uang yang besar, sedangkan mereka tidak memiliki simpanan, ${ }^{28}$ sehingga mau tidak mau mereka harus meminjam kepada rentenir demi memenuhi kebutuhannya. Aspek kemudahan dalam meminjam uang tanpa adanya jaminan yang mendorong masyarakat untuk nekat melakukan pinjaman kepada rentenir. ${ }^{29}$

Kekuasaan uang mengacu pada kemampuannya untuk membeli segala macam kebutuhan, baik bidang ekonomi maupun non ekonomi. Uang bukan lagi menjadi sarana transaksi tetapi juga menjadi tujuan dari aktivitas sosial dalam masyarakat. Sehingga, kebanyakan orang mendapatkan uang bukan hanya untuk memenuhi kebutuhan ekonomi tetapi untuk memperoleh kekuatan sosial. Keadaan tersebut sesuai dengan pernyataan Marx yang menyatakan bahwa pengejaran kekuatan sosial ekonomi melalui uang akan membawa pada alienasi sosial. ${ }^{30}$

\section{Dampak Sosiologi Masyarakat}

Mengenai praktek rentenir yang ada di Indonesia memiliki dampak tersendiri bagi masyarakat yang melakukan peminjaman uang kepada rentenir. Adapun dampak sosiologi masyarakat yaitu:

a. Keadilan

Praktek rentenir dapat mengakibatkan pendapatan yang diperoleh secara tidak adil. Para pelaku rentenir dituntut untuk selalu untung saat mengolah uang

26 Utia Khasanah, Muh. Wahyuddin Abdullah dan Amiruddin, "Dampak Praktik Rentenir Terhadap Kesejahteraan Pedagang Eceran Dalam Perspektif Ekonomi Islam,” Jurnal Hukum Ekonomi Syariah Vol. 3, no. 1 (2019): hlm. 17.

27 Sumitro Djojohadikusumo, Kredit Rakyat Di Masa Depresi (Jakarta: LP3ES, 1989), hlm. 8.

28 Djojohadikusumo, Kredit Rakyat Di Masa Depresi, hlm. 15.

29 Abduh Al-Baraq, Bukan Dosa Ternyata Dosa (Yogyakarta: Pustaka Grhatama, 2010), hlm. 53.

30 Heru Nugroho, Uang, Rentenir, dan Hutang Piutang di Jawa, hlm. 124.

Website: http://jurnal.radenfatah..ac.id/index.php/ieconomics 
pinjaman, sehingga orang yang meminjam dipaksa untuk mengembalikan dana pinjaman beserta bunganya.

b. Keluarga

Keluarga umumnya mengambil pinjaman untuk memenuhi kebutuhan yang lebih tinggi. Pada dasarnya, mereka mampu memenuhi kebutuhan seharihari, akan tetapi belum mampu untuk memenuhi kebutuhan yang lebih besa. Pembayaran bunga yang tinggi pada sistem rentenir mengakibatkan suatu keluarga untuk memberikan sebagian pendapatan mereka kepada pihak yang memiliki modal. Di samping itu, kecemasan yang terjadi secara terus-menerus juga dapat berakibat pada kehidupan pribadi dan keluarga. ${ }^{31}$

c. Kemiskinan

Konsep kemiskinan mengacu pada perkiraan tingkat pendapatan dan kebutuhan. Dengan memenuhi kebutuhan pokok atau kebutuhan dasarnya setiap orang berhak untuk hidup secara baik. Tetapi jika seseorang tidak memiliki pendapatan yang mencapai taraf minimum, maka orang tersebut dapat dikategorikan miskin. Sehingga taraf kemiskinan dapat diukur dengan membandingkan antara tingkat pendapatan yang dibutuhkan dengan tingkat pendapatan seseorang untuk mendapatkan kebutuhan dasarnya. ${ }^{32}$

d. Psikologis

Maulana Mududi menjelaskan bahwa bunga adalah sumber kejahatan dan bahaya. Bunga dapat menghancurkan dan menyengsarakan manusia melalui pengaruhnya terhadap karakter manusia. Kondisi psikologis seseorang akan cenderung berubah, diantaranya adalah adanya perasaan cinta terhadap uang dan keinginan untuk mengumpulkan harta demi kepentingan pribadi tanpa memperhatikan perintah dan peringatan agama. ${ }^{33}$

\section{Bentuk Hubungan Sosiologi Masyarakat}

Hubungan sosiologi masyarakat terjadi karena disebabkan oleh beberapa kategori yaitu:

a. Hubungan Tetangga

Para rentenir pada umumnya tidak memberikan pinjaman kepada tetangga disekitar tempat tinggalnya, ini disebabkan karena praktek rentenir yang mereka jalani pada dasarnya tidak diketahui oleh tentangga. Mereka akan mencari nasabah

31 Muh. Al Juned, "Dampak Praktek Rentenir Terhadap Sosial Ekonomi di Kelurahan Gunung Sari Kec. Rappocini Makassar” (Skripsi, Makassar, UIN Alaudin Makassar, 2014), hlm. 45-46.

32 Utia Khasanah, "Pengaruh Praktik Rentenir Terhadap Tingkat Kemiskinan Masyarakat" (Skripsi, Makassar, UIN Alaudin Makassar, 2014), hlm. 35.

33 Muh. Al Juned, "Dampak Praktek Rentenir Terhadap Sosial Ekonomi di Kelurahan Gunung Sari Kec. Rappocini Makassar” (Skripsi, Makassar, UIN Alaudin Makassar, 2014), hlm. 43-44.

Website: http://jurnal.radenfatah..ac.id/index.php/ieconomics 
yang jauh dari lingkungan tempat tinggalnya walaupun harus mengeluarkan dana dalam pengutipan cicilan. Namun, tidak menutup kemungkinan bagi para rentenir untuk meminjamkan dana kepada tetangga sekitarnya apabila dalam keadaan mendesak. ${ }^{34}$

b. Hubungan Bisnis

Hubungan bisnis adalah hubungan yang jarang terjadi dalam praktik rentenir, ini disebabkan oleh praktek rentenir yang umumnya ditutupi oleh pasangan si rentenir yang ada di satu tempat pekerjaannya. ${ }^{35}$

c. Hubungan Pertemanan

Hubungan pertemanan antara nasabah dan rentenir adalah salah satu kesempatan besar untuk menjalankan praktek rentenirisasi. Melalui hubungan ini, informasi tentang praktek rentenir akan mudah diketahui oleh satu teman ke teman yang lainnya. Sehingga jumlah nasabah akan bertambah dan dapat mengurangi resiko yang kemungkinan terjadi dalam masa pembayaran cicilan. Di sisi lain, timbal balik yang diperoleh bagi teman dari rentenir ini adalah mendapatkan sedikit keuntungan saat melakukan pinjaman, misalnya perpanjangan waktu cicilan dan lain-lain. ${ }^{36}$

d. Hubungan Kepercayaan

Kepercayaan merupakan hubungan dasar yang harus dimilliki oleh rentenir dengan nasabahnya. Adanya kepercayaan antara rentenir dan nasabah akan menjadi basis dari transaksi kredit. Perlakuan para rentenir terhadap nasabahnya dapat dilihat dari derajat kepercayaan yang mereka kembangkan, sehingga para rentenir akan memperlakukan nasabahnya dengan cara yang berbeda. ${ }^{37}$

e. Hubungan Keterlekatan

Hubungan keterlekatan akan terbentuk apabila ada timbal balik antara rentenir dan nasabah, atau dalam kata lain kedua belah pihak sudah merasa diuntungkan dan saling membutuhkan satu sama lain. ${ }^{38}$

f. Hubungan Eksploitasi

Hubungan eksploitasi akan dirasakan oleh nasabah apabila bunga yang ditetapkan oleh rentenir terlalu tinggi dalam sistem pinjaman, ini diakibatkan

34 Rossi Susilawati, "Pola Hubungan Sosial Antara Rentenir dengan Nasabahnya di Kelurahan Palas Kecamatan Rumbai Kota Pekanbaru," JOM FISIP , vol. 3, no. 2 (2016), hlm. 7.

35 Rossi Susilawati, "Pola Hubungan Sosial Antara Rentenir dengan Nasabahnya di Kelurahan Palas Kecamatan Rumbai Kota Pekanbaru," hlm. 7.

36 Rossi Susilawati, "Pola Hubungan Sosial Antara Rentenir dengan Nasabahnya di Kelurahan Palas Kecamatan Rumbai Kota Pekanbaru," hlm. 7.

37 Yoserizal Yessi, "Hubungan Sosial Antara Rentenir dan Nasabah", Seminar Nasional, 2013, hlm. $11-12$.

38 Rossi Susilawati, "Pola Hubungan Sosial Antara Rentenir dengan Nasabahnya di Kelurahan Palas Kecamatan Rumbai Kota Pekanbaru," Jurnal JOM FISIP , Vol. 3, no. 2 (2016), hlm. 4.

Website: http://jurnal.radenfatah..ac.id/index.php/ieconomics 
karena rentenir memiliki hak dalam penentuan jaminan. Apabila salah satu pihak merasa dirugikan maka hubungan konflik akan terjadi di antara keduanya, dan sebaliknya, jika kedua belah pihak merasa saling diuntungkan maka akan menimbulkan ketergantungan satu sama lain. ${ }^{39}$

g. Hubungan Pertikaian

Pertentangan yang terjadi antara rentenir dan nasabahnya tidak selalu dicerminkan sebagai tindakan kekerasan yang melibatkan fisik, akan tetapi bisa menyangkut dengan masalah hati. Hal ini didasari oleh perbedaan tuntutan antara kedua belah pihak terkadang tidak sama. ${ }^{40}$

h. Hubungan Ketergantungan

Ketergantungan antara rentenir dengan nasabahnya dapat terjadi karena para nasabah memberikan incom berupa profit dari bunga pinjaman kepada rentenir, di sisi lain pihak rentenir memberikan bantuan kepada para nasabah dalam memenuhi kebutuhannya terhadap uang. ${ }^{41}$

\section{METODOLOGI PENELITIAN}

Jenis penelitian ini adalah penelitian lapangan (field research). Penelitian lapangan dilakukan dalam kancah kehidupan yang sebenarnya..42 Dalam penelitian ini data yang diperoleh terdiri dari data primer dan data sekunder. Dengan sumber primer dan sekunder diharapkan memperoleh data yang akurat sesuai yang diharapkan dalam penelitian dan dapat menemukan jawaban atas permasalahan. Dalam rangka mengumpulkan data, penulis menggunakan metode pengumpulan observasi atau pengamatan, wawancara, dokumentasi

Dengan demikian penelitian pendekatan kualitatif yang bersifat deskriptif dilakukan dengan cara memaparkan informasi-informasi yang akurat yang diperoleh dari masyarakat di Kecamatan Punggur Lampung Tengah yang berkaitan dengan praktik rentenirisasi. Sehingga mendapatkan keadaan dan praktik yang berlangsung dalam kegiatan usaha tersebut kemudian mengevaluasinya dengan berbagai teori yang berkaitan dengan pokok permasalah dalam penelitian ini.

39 Rossi Susilawati, "Pola Hubungan Sosial Antara Rentenir dengan Nasabahnya di Kelurahan Palas Kecamatan Rumbai Kota Pekanbaru," hlm. 4-5.

40 Yoserizal Yessi, “Hubungan Sosial Antara Rentenir dan Nasabah”, hlm. 11-12.

41 Yoserizal Yessi, “Hubungan Sosial Antara Rentenir dan Nasabah”, hlm. 11-12.

42 Lexy J. Muleong, Metodologi penelitian kualitatif, Cet. XXVI (Bandung: PT Remaja Rosdakarya, 2009), hlm. 208.

Website: http://jurnal.radenfatah..ac.id/index.php/ieconomics 
Vol 6. No 1. Juni 2020

\section{PEMBAHASAN}

\section{Praktik Rentenir Dalam Perspektif Ekonomi Islam}

Menelisik jauh lebih dalam, di kecamatan punggur sering terjadi praktik rentenirisasi dikarenakan terkadang masyarakat sudah tidak lagi mendapatkan jalan keluar untuk mengatasi problematika keuangnnya dan juga ketika msyarakat ingin melakukan peminjaman di bank atau lembaga keuangan mereka menemukan prosedur yang rumit dan sulit. Oleh karena mereka berfikir untuk mencari alternatif lain yaitu dengan menggunakan jasa rentenir tersebut.

Rentenir merupakan perjanjian pinjam-meminjam uang disertai dengan bunga merupakan salah satu bentuk perjanjian yang dikenal oleh masyarakat Indonesia, dan hal ini dapat dikatakan telah membudaya. Namun, khusus bagi umat Islam perbuatan ini dikenal sebagai riba yang diharamkan menurut ajaran Islam sebagaimana ditegaskan dalam Al-Qur'an dan Hadits.

Lebih jauh dikatakan dalam sistem hukum positif Indonesia, perjanjian pinjammeminjam yang disertai bunga merupakan suatu bentuk perjanjian yang lahir berdasarkan atas kepakatan antara pemilik uang dan pihak peminjam. Perjanjian semacam ini, di satu pihak dikenal atau diperbolehkan baik dalam sistem Hukum Adat maupun dalam sistem Hukum Perdata, dan di lain pihak tidak ada larangan dalam Hukum Pidana (khususnya tindak pidana perbankan). Sehingga sangat keliru kalau seseorang yang meminjamkan uang dengan bunga dikatakan menjalankan praktik bank gelap.

Pada dasarnya, yang dmaknai dengan bank gelap adalah orang atau pihak-pihak yang menjalankan kegiatan yang seolah-olah bertindak sebagai bank atau lebih dikenal dalam masyarakat adalah rentenir. Sehingga dalam kegiatannya sangat berlawanan dengan hukum, baik hukum tertulis atau hukum ketetuan agama. Dalam kasus rentenir yang dikenal oleh masyarakat, sebenarnya bukan terjadi berdasarkan hukum akan tetapi hanyalah penyalagunaan yang sedang dihadapkan oleh orang tersebut. Hal ini dapat pula dikatakan sebagai peyalagunaan kepercayaan seseorang untuk melakukan kegiatan yang berhubungan dengan kegiatan perputaran uang dalam lingkup secara mikro.

Hal ini pulahlah yang terjadi masyarakat Kecamatan Punggur. Dalam kegiatannya, rentenir yang terjadi dikalangan masyarakat banyak yang mengatakan bahwa kegiatan semacam rentenir sangat menunjang bagi masyarakat karena mampu membantu masyarakat yang keuangannya menipis. Hal ini Sejalan dengan hasil wawancara terhadap salah satu warga di Kecamatan Punggur yaitu bapak yang berinisial $\mathrm{K}$ (karena tidak mau di expose namanya) mengatakan bahwa dampak dari pihak rentenir menetapkan bunga pinjaman sangat tinggi, dan dampaknya sangat

mengagetkan sekali karena disama ratakan, maksudnya yang meminjam kalau

Website: http://jurnal.radenfatah..ac.id/index.php/ieconomics 
terlambat bayar langsung menyita barang-barang dan apabila si peminjam yg tidak mampu membayar akan berimbas kepada pendidikan anak-anaknya, yang tidak punya uang langsung saja memberhentikan anakanaknya untuk tidak sekolah lagi.43

Dari hasil wawancara tersebut di atas jelas bahwa dalam kegiatan rentenir, cara kerjanya sangat menunjang masyarakat. Hal inilah yang terjadi di kalangan masyarakat Kecamatan Punggur. Namun disamping kegiatannya yang sangat menunjang masyarakat, terdapat pula dampak yang langsung dirasakan oleh masyarakat. Hal ini diperjelas dengan berbagai keluhan-keluhan yang dialami oleh masyarakat ketika pembayaran tagihannya yang terlalu besar tingkat bunganya.

Untuk itu, dalam kegiatan yang dilakukan oleh rentenir kebanyakan masyarakat mendapatkan masalah ketika dalam pembayaran tagihan. Salah satunya adalah pihak rentenir tidak segan-segan memakai bodigar atau orang bayaran untuk menagih pihak yang meminjam uang. Dampak tersebut yang dikeluhkn oleh pihak peminjam uang, sebagaimana hasil wawancara dengan salah satu masyarakat di Kecamatan Punggur. Bapak berinisial D mengatakan bahwa, Saya ragu karena pihak rentenir menetapkan bunga pinjaman sangat tinggi, dan dampaknya sangat mengangetkan sekali karena disama ratakan, maksudnya yang meminjam kalau terlambat bayar langsung menyita barang-barang. Selain itu, banyak masyarakat yang tidak mampu membayar, dan berimbas pada pendidikan anak-anaknya. Yang tidak punya uang langsung saja memberhentikan anaknya untuk tidak sekolah lagi karena fokus mencari uang untuk membayar penjaman ke rentenir.44

Sesuai dengan hasil wawancara diatas, maka dapat difahami bahwa praktek rentenir dikalangan masyarakat sangat berdampak negetif terhadap ekonomi masyarakat. Demikian pula praktek rentenir yang dilakukan di kalangan masyarakat Kecamatan Punggur. Karena menurut salah satu warga, sebagaimana wawancara yang telah dilakukan, bahwa perekonomian masyarakat sangat terganggu baik untuk kebutuhan ssehari-hari bahkan untuk kebutuhan pendidikan.

Dengan melihat hasil wawancara diatas, maka dapat disimpulkan bahwa penelitian ini sejalan dengan Teori yang dikemukakan oleh Dale W Adam, yang menyatakan bahwa rentenir adalah individu yang memberikan kredit jangka pendek, tidak menggunakan jaminan yang pasti, dan bunga relative tinggi serta selalu berusaha melanggengkan kredit dengan masyarakat.45 Maksud dari tidak menggunakan jaminan yang pasti adalah masyarakat yang melakukan peminjaman uang terhadap rentenir tidak serta merta diberikan kepastiaan pelunasannya dilakukan. Yang pasti, kapanpun

43 Hasil Wawancara, 10 Januari 2020.

44 Hasil Wawancara, 10 Januari 2020.

45 Khudzaifah Dimyati, Profil Praktek Pelepasan Uang (Rentenir) dalam Masyarakat Transisi. Universitas Diponegoro (Semarang, 1997), hlm. 16.

Website: http://jurnal.radenfatah..ac.id/index.php/ieconomics 
pihak rentenir ingin menagih uangnya diperbolehkan. Padahal dalam hukum perbankan tidak demikian.

Disamping itu, hasil ini sangat sejalan dengan penelitian Dasar yang telah dibukukan bahwa praktek rentenir erat kaitannya dengan aspek sosial, budaya dan moral. Dikatakan erat kaitannya karena dalam praktek rentenir masyarakat terkadang kepercayaannya diabaikan oleh pihak rentenir. Maka hasil penelitian dapat disimpulkan bahwa praktik rentenir dalam ekonomi sangat merugikan masyarakat karena dalam kegiatannya, rentenir yang berkembang di kalangan masyarakat Kecamatan Punggur banyak mendapat hambatan khususnya bagi masyarakat yang berpendidikan tinggi.

Begitu maraknya saat ini terjadi praktek-praktek riba/rentenir, yang begitu besar sehingga berakibat terhadap ketenangan dan ketentraman masyarakat. Betapa tidak, sudah banyak korban-korban praktek rentenir berjatuhan, yang berakibat hancurnya ekonomi rumah-tangga, tercerai-berainya kehidupan berumah-tangga, karena dikejarkejar oleh bunga rentenir yang mencekik leher masyarakat.

Rentenir yang dikenal oleh sebagian besar masyarakat muslim di Indonesia, tentunya sudah tidak asing lagi untuk diperbincangkan. Namun yang menjadi masalah besar selanjutnya adalah banyaknya praktek rentenir yang tidak sejalan dengan akad pinjam meminjam. Yang sangat disayangkan lagi adalah kurangnya pemahaman masyarakat tentang halalnya akad dalam pinjam meminjam. Seperti yang terjadi di Kecamatan Punggur, dimana masyarakat yang melakukan praktek rente tidak mengetahui bahwa yang dilakukannya tidak jauh berbeda dengan praktek riba. Hal ini diperkuat oleh pengakuan salah seorang tokoh agama di Kecamatan Punggur pada saat melakukan wawancara langsung.

H. Zuaeni selaku tokoh masyarkat di Kecamatan Punggur mengatakan, praktek rentenir yang dilakukan oleh masyarakat Kecamatan Punggur sebenarnya sudah menjurus kepada hal-hal yang berbau riba. Sedangkan riba dalam Islam adalah haram maka kalau menurut islam, rentenir sudah pasti haram. Artinya, kegiatannya sama sekali tidak mengajarkan masyarakat kepada yang disarankan ajaran islam padahal $80 \%$ yang terlibat didalam prektek rente baik si peminjam maupun yang meminjamkan uang adalah orng-orang beragama Islam. 46

Dengan adanya penjelasan diatas, sudah jelas bahwa praktek rente yang dilakukan pada masyarakat Kecamatan Punggur sudah termasuk praktek riba sedangkan yang dimaksud disini ialah rente itu sama dengan jual beli, sama-sama haramnya karena mereka berlebihan dalam keyakinannya, bahwa rente dan riba itu

46 Hasil Wawancara, 10 Januari 2020.

Website: http://jurnal.radenfatah..ac.id/index.php/ieconomics 
dijadikannya sebagai pokok dan hukumnya adalah haram. Sehingga dipersamakan dengan jual beli.

Oleh karena itu hasil ini dapat disimpulkan bahwa, tinjauan ekonomi Islam terhadap rentenir sangat bertentangan dengan hukum dan syariat Islam. Maka tidak diwajibkan kepada orang muslim untuk melaksanakan kegiatan rente. Dan khususnya masyarakat Kecamatan Punggur, setidaknya dapat meninggalkan praktek rente yang telah berkembang disana. Karena mereka yang melakukan praktek riba, hidup dalam situasi gelisah, tidak tentram, selalu bingun dan berada dalam ketidakpastian, yang disebabkan kerena pikiran mereka yang tertuju kepada materi dan penambahan harta semata.

\section{Praktik Rentenir Dalam Perspektif Sosiologi Masyarakat}

Berdasarkan penelitian yang dilakukan ada beberapa hubungan sosial yang terjalin yang biasanya menjadi awal mulanya praktik rentenir ini terjadi, :

a. Hubungan Tetangga

Berdasarkan hasil penelitian yang telah dilakukan, hanya satu orang dari peminjam yang diteliti merupakan tetangga dari rentenir tersebut. Menurut hasil penelitian, para rentenir ini enggan meminjamkan ke tetangga mereka disebabkan praktek rentenir yang mereka jalani pada umumnya tidak diketahui oleh tetangga sekitar tempat tinggalnya. Para rentenir lebih memilih para peminjam yang jauh dari kawasan rumahnya walaupun harus lebih banyak mengeluarkan dana dalam pengutipan cicilan. Tetapi, meskipun demikian para rentenir tidak menutup kemungkinan memberi pinjaman pada tetangga jika sangat terdesak.

b. Hubungan Bisnis

Hubungan bisnis merupakan bentuk hubungan yang jarang terjadi antara rentenir dengan peminjamnya. Ini terbukti berdasakan hasil penelitian hanya satu diantara peminjam yang mempunyai hubungan bisnis dengan rentenir. Berdasarkan hasil penelitian, peminjam ini meminjam berdasarkan rekomendasi dari pasangan si rentenir yang satu tempat pekerjaan dengannya. Bentuk hubungan ini jarang terjadi disebabkan karena praktek rentenir ini umumnya ditutupi oleh pasangan si rentenir. Tetapi tidak menutup kemungkinan ini juga dapat terjadi karena merupakan kesempatan bagi si rentenir itu sendiri.

c. Hubungan Pertemanan

Hubungan pertemanan antara rentenir dengan peminjamnya merupakan kesempatan besar bagi si rentenir menjalankan praktek ini. Melalui satu teman yang telah melakukan pinjaman maka akan menjadi seperti pesan berantai terhadap teman yang lainnya. Hubungan kedekatan seperti ini cenderung meningkatkan jumlah peminjam dan mengurangi resiko yang bisa terjadi dalam masa pembayaran cicilan. Peminjam yang merupakan teman dari rentenir juga

Website: http://jurnal.radenfatah..ac.id/index.php/ieconomics 
akan memperoleh sedikit keuntungan ketika melakukan pinjaman, bisa seperti perpanjangan waktu cicilan dan lain-lain. Sementara si rentenir pun tidak terlalu mencemaskan peminjam tersebut disebabkan merupakan teman rentenir tersebut.

d. Hubungan Kepercayaan

Kepercayaan merupakan hal penting dan hal yang mendasari dalam praktek rentenir ini. Melalui sebuah kepercayaan maka terbentuk suatu hubungan antara rentenir dan peminjamnya. Kepercayaan bisa menjadi tolak ukur yang digunakan rentenir dalam praktek pinjam-meminjam ini, jika rentenir mempercayai peminjam tersebut maka nasabah tersebut akan memperoleh beberapa kemudahan, begitu juga sebaliknya. Bentuk kepercayaan yang diberikan oleh rentenir kepada nasabahnya, yaitu :

1) Memberikan pinjaman tanpa ada jaminan

2) Memberikan kelonggaran waktu pada pembayaran cicilan

3) Peminjam bisa menjadi penjamin bagi Peminjam baru yang lainnya

4) Peminjam bisa mendapatkan pinjaman yang mendesak ataupun pinjaman yang cukup besar

e. Hubungan Keterlekatan

Setelah hubungan kepercayan terbangun, maka hubungan keterlekatan pun akan terbangun juga. Keterlekatan merupakan tindakan ekonomi yang disituasikan secara sosial dan melekat dalam jaringan sosial personal yang sedang berlangsung diantara para aktor. Adapun yang dimaksud dengan jaringan hubungan sosial adalah sebagai suatu rangkaian hubungan yang teratur atau hubungan sosial yang sama diantara individu-individu atau kelompok-kelompok. Cara seorang Peminjam ataupun rentenir didalam membangun hubungan keterlekatan akan berpengaruh pada tindakan-tindakan dalam praktek ini. Dengan kepercayaan yang sudah ada, maka kedua belah pihak pun ingin mempertahankan hubungan tersebut. Salah satu cara yang diambil ialah berusaha mendekatkan diri dan mengenal dengan baik nasabah ataupun rentenir tersebut. Ini dimaksudkan agar Peminjam dapat juga melakukan tindakan yang diharapkan rentenir seperti tepat pada waktu pembayaran, tidak berpindah ke rentenir lain dan lain-lain. Begitu juga sebaliknya, Peminjam mengharapkan rentenir memberikan bunga yang rendah, penambahan waktu pelunasan cicilan, atau tanpa jaminan dan lain-lain.

f. Hubungan Eksploitasi

Walaupun keadaan ini disadari oleh para Peminjam tetapi mereka tetap saja menggunakan jasa rentenir ini, berikut tanggapan masyarakat terhadap suku bunga yang ditetapkan rentenir, mereka mengatakan bahwa bunga yang ditetapkan ialah

Website: http://jurnal.radenfatah..ac.id/index.php/ieconomics 
tinggi.47 Ini berarti bahwa rentenir telah melakukan eksploitasi pada Peminjam untuk memperoleh keuntungan yang besar.

g. Hubungan Pertikaian

Didalam praktek rentenir tentu saja ada konflik atau pertikaian yang bisa atau akan terjadi. Ini disebabkan karena adanya perbedaan kepentingan antara Peminjam dan rentenir. Konflik disini tidak hanya sebatas perlakuan fisik tetapi juga meliputi konflik perasaan atau hati, kewajiban dan hak antara kedua belah pihak yang tidak sesuai dengan harapan. Konflik merupakan situasi yang wajar dalam setiap masyarakat, bahkan tidak ada satu masyarakat pun yang tidak pernah mengalami konflik, baik konflik yang cukup besar maupun kecil.

Didalam menjalankan usahanya, terkadang ada beberapa peminjam yang menunggak untuk pembayaran cicilan maupun hingga melarikan diri dari kewajbannya. Tentu saja ini menjadi penyebab konflik diantara mereka, tetapi tidak semua masalah yang ada diselesaikan dengan cara kekerasan oleh rentenir, akan tetapi biasanya rentenir akan melakukan penyitaan atas barang jaminan, biasanya tanah, rumah, dan juga kendaraan.

h. Hubungan Saling Ketergantungan

Saling ketergantungan merupakan hasil dari orientasi-orientasi nilai yang dianut bersama oleh pihak pihak yang berinteraksi dan penyesuaian diri dengan harapan-harapan orang lain guna memenuhi kebutuhan masing-masing pihak. Dasar yang membentuk hubungan ini adalah komitmen terhadap nilai-nilai yang dianut bersama untuk memenuhi kebutuhan masing-masing. Ada semacam hubungan timbal balik antara rentenir dengan Peminjam nya, dimana para Peminjam memberi keuntungan dari bunga yang ditetapkan dan rentenir memenuhi jumlah pinjaman yang diinginkan Peminjam.

\section{SIIMPULAN}

Menurut perspektif ekonomi islam terhadap praktek rentenir di masyarakat yaitu sangat bertentangan dengan hukum dan syariat islam. Maka tidak diwajibkan kepada orang muslim untuk melaksanakan kegiatan rentenir. Dan khusus Kecamatan Punggur, setidaknya dapat meninggalkan praktek rentenir yang telah berkembang di masyarakat karena mereka yang melakukan praktek riba, hidup dalam situasi gelisah, tidak tentram, selalu bingung dan berada dalam ketidakpastian, yang disebabkan kerena pikiran mereka yang tertuju kepada materi dan penambahan harta semata

Menurut perspektif sosiologi masyarakat rentenir merupakan sebuah fenomena yang nyata dan ada sejak dulu. Pada masyarakat Kecamatan Punggur rentenir bukanlah hal yang

47 Hasil Wawancara, 10 Januari 2020.

Website: http://jurnal.radenfatah..ac.id/index.php/ieconomics 
tabu karena pada umumnya masyarakat di Kecamatan Punggur menggunakan jasa rentenir ini. Rentenir merupakan agen kapitalis yang seluruh aktivitasnya untuk mencari keuntungan melalui jumlah bunga yang ditetapkan oleh rentenir itu sendiri. Rentenir dalam kehidupan sehari-hari sangat mudah untuk ditemui dan bahkan aktivitas mereka terlihat jelas bagi masyarkat umum. Maka tak heran jika masyarakat mengganggap negatif terhadap praktek ini, walaupun para peminjam yang melakukan pinjaman beranggapan positif tentang keberadaan rentenir ini. Para rentenir ini menjadi solusi bagi para sebagian masyarakat untuk memenuhi kebutuhan hidupnya. Kemudahan-kemudahan yang diberikan seperti besar pinjaman, waktu yang lebih cepat dan efisien, cara membayar, tanpa jaminan, dan kesepakatan-kesepakatan lain menjadi pertimbangan masyarakat ketika melakukan pinjaman. Kesulitan yang dihadapi rentenir dengan prosedur peminjaman yang mudah ini adalah adanya beberapa peminjam yang terlambat membayar cicilan ataupun bahkan sampai melarikan diri karena tidak sanggup membayar. Pekerjaan rentenir ini merupakan usaha milik sendiri tanpa ada kerja sama dengan pihak lain. Perbuatan yang melanggar hukum ialah jika rentenir melakukan tindakan kekerasan kepada peminjamnya.

\section{DAFTAR PUSTAKA}

Al Juned, Muh. "Dampak Praktek Rentenir Terhadap Sosial Ekonomi di Kelurahan Gunung Sari Kec. Rappocini Makassar.” UIN Alaudin Makassar, 2014.

Al-Baraq, Abduh. Bukan Dosa Ternyata Dosa. Yogyakarta: Pustaka Grhatama, 2010.

Al-Bigha, Mustafa Daib. Tadzhib: Kompilasi Hukum Islam Ala Madzhab Syafi'i. Surabaya: Al-Hidayah, 2008.

Al-Kaaf, Abdullah Zaky. Ekonomi dalam Perspektif Islam. Bandung: PT. Pustaka Setia, 2002.

Al-Qur'an surat Al-Baqarah : 275.

Al-Qur'an Surat Al-Imron :130.

Al-Qur'an surat Ar-Ruum [30] : 39.

Chici Amedea dan Mira Hasti Hasmira. "Pemanfaatan Utang Oleh Ibu-ibu Rumah Tangga

Pada Rentenir di Jorong Kuranji Kecamatan Guguak VIII Koto Kabupaten Lima Puluh Kota.” Jurnal Perspektif: Jurnal Kajian Sosiologi dan Pendidikan Vol. 3, no. 1 (2020).

Cica. "Dampak Praktik Rentenir Terhadap Kesejahteraan Ekonomi Masyarakat Di Kelurahan Pattinggalloang Baru Kecamatan Ujung Tengah Makassar.” Skripsi, Universitas Alauddin Makassar, 2018.

Dianti, Flora. "Hukum Online.Com." Diakses 23 Februari 2020. https://m.hukumonline.com/klinik/detail/ulasan/it4e91424b20cbe/dapatkahrentenir-dipidana-/.

Dimyati, Khudzaifah. Profil Praktek Pelepasan Uang (Rentenir) dalam Masyarakat Transisi. Universitas Diponegoro. Semarang, 1997.

Djojohadikusumo, Sumitro. Kredit Rakyat Di Masa Depresi. Jakarta: LP3ES, 1989.

Website: http://jurnal.radenfatah..ac.id/index.php/ieconomics 
Fachruddin, Fuad Mohd. Riba dalam Bank, Koperasi, Perseroan dan Assuransi. Bandung: PT Al-Ma'arif, 1993.

Frans E. Panjaitan dan Nofrion Ratna Wilis. "Praktik Pelepasan Uang/Rentenir di Nagari Lubuk Basung Kabupaten Agam Sumatera Barat.” Jurnal Buana Vol. 2, no. 1 (2018).

Harun. "Riba Menurut Pemikiran M. Quraish Shihab." Suhuf 27, no. 1 (Mei 2015).

Hasil Wawancara, 10 Januari 2020.

— 10 Januari 2020.

Institut Bankir Indonesia. Bank Syariah: Konsep, Produk dan Implementasi Operasional. Jakarta: Djambatan, 2001.

J. Muleong, Lexy. Metodologi penelitian kualitatif. Cet. XXVI. Bandung: PT Remaja Rosdakarya, 2009.

Khasanah, Utia. "Pengaruh Praktik Rentenir Terhadap Tingkat Kemiskinan Masyarakat." UIN Alaudin Makassar, 2014.

Luthfi, Muhammad. "Praktik Rentenir Dalam Perspektif Hukum Ekonomi Syariah." Tesis, Universitas Islam Negeri Antasari Banjarmasin, 2018.

Manan, H. Abdul. Pembahatuan Hukum Islam di Indonesia. Depok: Kencana, 2017.

Moh. Zainol Aried dan Sutrisni. "Praktik Rentenir Penghambat Terwujudnya Sistem Hukum Perbankan Syariah di Kabupaten Sumenep." Jurnal Performance Vol. III, no. 2 (2013).

Nugroho, Heru. "Uang Rentenir dan Hutang Piutang di Jawa." Disertasi Universitas Bielefeld, 1993.

Nurhayati. "Memahami Konsep Syariah, Fikih, Hukum, dan Ushul Fikih." Jurnal Hukum Ekonomi Syariah Vol. 2, no. 2 (2018).

Parlina, Yeyen. "Praktik Pinjaman Renternir dan Perkembangan Usaha Pedagang di Pasar Prapatan Penjalin Majalengka." Jurnal Inklusif Vol. 2, no. 2 (2017).

Quthhb, Sayyid. "Fi Zhilal al-Qur'an." Dar al-Fikr IV (t.t.): 74.

Rahman, Fazlur. Doktirn Ekonomi Islam. Yogyakarta: PT. Dana Bhakti Wakaf, 1995.

Siboro, Ilas Korwadi. "Rentenir (Analisis Terhadap Fungsi Pinjaman Berbunga Dalam Masyarakat Rokan Hilir Kecamatan Bagan Sinembah Desa Bagan Batu).” Jurnal Jom Fisip Vol. 2, no. 2 (2015).

Subekti, R. Aneka Perjanjian, 1985.

Susilawati, Rossi. "Pola Hubungan Sosial Antara Rentenir dengan Nasabahnya di Kelurahan Palas Kecamatan Rumbai Kota Pekanbaru." JOM FISIP 3, no. 2 (t.t.).

urjaman, Jajang. "Peranan Baitul Mall Wattamwil Dalam Mengatasi Dampak Negatif Praktek Rentenir." UIN Syarif Hidayatullah, 2010.

Utia Khasanah, Muh. Wahyuddin Abdullah dan Amiruddin. "Dampak Praktik Rentenir Terhadap Kesejahteraan Pedagang Eceran Dalam Perspektif Ekonomi Islam.” Jurnal Hukum Ekonomi Syariah Vol. 3, no. 1 (2019).

Wawancara. Pihak Peminjam, 10 Januari 2020.

- Pihak Peminjam, 10 Januari 2020.

Yessi, Yoserizal, dan Wahyu Sari Yeni. "Hubungan Sosial Antara Rentenir dan Nasabah (Suatu Studi Tentang Rentenir di Kota Pekanbaru),” t.t.

Website: http://jurnal.radenfatah..ac.id/index.php/ieconomics 
I-Economic: A Research Journal on Islamic Economics

ISSN 2548-5601, e-ISSN 2548-561X

Vol 6. No 1. Juni 2020

Yuliyani. "Konsep dan Peran Strategi Ekonomi Syariah Terhadap Isu Kemiskinan.” Jurnal Iqtishadia Vol. 8, no. 1 (2015).

Zayd, Abd al-'azhim Jalal Abu. "Fiqh al-Riba Dirasah Muqaranah wa Syamilah li Tathbiqat al-Mu'ashirah.” Bayrut: Mu'assasah al-Risalah, 1425.

Website: http://jurnal.radenfatah..ac.id/index.php/ieconomics 